\title{
Second International Congress for Microbiology
}

$\mathrm{T}^{\mathrm{H}}$ HE week of July 27-August 1 saw more than a thousand microbiologists from all over the world united in conference at University College under the presidency of Dr. J. C. G. Ledingham, director of the Lister Institute. Six years have elapsed since the first Congress in Paris, the original triennial plan having fallen through for reasons which, in view of the world-wide political and economic unrest, may readily be imagined. Much new and important work was therefore ripe for discussion, and the scientific programme had to be divided into no less than eight sections, devoted each to a special subject.

Section 1, under the presidency of Prof. E. Gotschlich, formerly of Heidelberg and now of Ankara, Turkey, dealt with the general biology of micro-organisms. Selective bacteriostasis (the inhibitory action of such substances as dyestuffs and the products of their own metabolism on the growth of bacteria and fungi) and the preservation of microorganisms in suspended animation, so to speak, by drying in the frozen state were two of the subjects most actively discussed. Their importance is both theoretical and practical : the latter subject especially, interesting in itself in its implications as regards resting states in more highly organized living creatures, has become practically valuable, since it has been realized how subject to variation the unicellular microbe is during culture in the laboratory, particularly variation by loss of such original properties as virulence.

Section 2, devoted to the viruses and virus diseases in animals and plants, under the presidency of Prof. Doerr, of Basle, had perhaps the greatest body of observations to consider, nearly all new since 1930 . The five days of discussion, on the general characteristics of viruses, on the modes of transmission and paths of infection in virus diseases, on the evidence concerning the agency of viruses in the ætiology of new growths and on the mechanism of immunity in virus infection, with its practical applications, might alone have furnished material for a congress. Besides the plant diseases in which 'virus' was first discovered, the common cold and influenza, foot-andmouth disease of cattle, psittacosis, hydrophobia, yellow fever and malignant tumours were all considered in the light of their experimental production by filtrates from which all but 'ultra-microscopic' life had been removed. Astonishing progress was reported in measuring particles of living matter possessing such pathogenic properties, particles not much greater in size than the molecules of comparatively simple chemical compounds, in purifying them and in studying their behaviour in the body fluids of infected and immune subjects : it is gratifying to note how much of it lies to the credit of British research work.

As Bordet put it, in his address as past president to the general assembly of the Congress, "il n'est point de problème plus passionnant, puisqu'il cornporte l'étude de la vie dans ces mystérieuses profondeurs où les dimensions deviennent tellement petites que parfois l'on se demande si l'on est encore en presence d'êtres vivants et si les phénomènes qu'on observe ne sont pas dûs à des principes chimiques doués de propriétés imprévues." Yet these particles have been rendered visible and, as 'elementary bodies', have been collected in suspen. sions of which a dilution of a millionth or more may still produce disease, and multiply indefinitely. Whether they can so multiply apart from the living tissue is yet unsettled: it seems rather that their reproduction is inseparable from the living cell and may indeed be actually a derangement of the cell's own life process.

Section 3, on bacteria and fungi in relation to disease in man, animals and plants, under the joint presidency of Dr. E. J. Butler of the Agricultural Research Council and Prof. H. Zinsser of Harvard, seemed almost staid and commonplace after such adventures in the unknown. Its subjects of highest interest, perhaps, were (l) the general one, on the significance of serological and cultural types of the pathogenic bacteria and fungi in relation to epidemic, epizootic and epiphytotic outbreaks of disease, and (2) the special discussion on the pathogenic streptococci which appear to cause more varied and widespread human misery and death than any other bacterial species.

Section 4, on economic bacteriology, under the presidency of Prof. R. E. Buchanan of Iowa, U.S.A., had to be divided into three subsections : (a) dairy, (b) water, including sewage and industrial fermentations, and (c) soil microbiology. Each of these had its own specialists conferring on its particular problems, but joining with the other subsections for discussion of a subject of general interest, the metabolism of yeast.

In Section 5, on medical, veterinary and agricultural zoology, with Prof. E. Brumpt of Paris as its president, the most active discussion was that on typhus fever and the rickettsias, with chemotherapy of protozoal infections as a close second. The author of "Rats, Lice and History", Prof. Zinsser, appropriately opened the discussion on the former. The similarities and differences, clinical and serological, in the great 'typhus group' of fevers have all been defined in quite recent years; the biology of the infecting microbes, the rickettsias, is, moreover, of particular interest in relation to life-cycles in bacteria, a fascinating field scarcely yet open to exploration.

Section 6 , on serology and immunochemistry, was to have been presided over by the arch-priest of the doctrine of antigenic specificity, Prof. Landsteiner of the Rockefeller Institute. Unfortunately prevented, he was replaced by Dr. P. Hartley of the National Institute at Hampstead, himself a serologist of distinction. The study of antigenic structure-and especially of the structure of the new synthetic antigens, the subject of a joint discussion with Section 7 -as the new tool for investigating the architecture of living matter, took almost the whole week of the section's time, though it found a day for the significance of allergy in disease, both as a general hypothesis in pathology and as an explanation of such special cases as the cottondust asthma, recently elucidated by Prausnitz in Manchester.

Section 7, on microbiological chemistry, had, naturally, Sir Arthur Harden as its president, and 
a particularly long and varied list of contributions, ranging over growth factors in bacterial culture to the influence of substrate on the chemical potentialities of the cell.

Section 8 , on specific immunization in the control of human and animal diseases, was presided over by the veteran Prof. W. H. Park of New York. Its programme was the longest of all, since its subject is the immediate practical concern of health officers in every country, all of them anxious to compare notes and to learn new methods in the prophylaxis of disease. Whooping cough, pneumonia, cerebrospinal fever and the streptococcal infections already mentioned were the chief human diseases in which progress was reported in protective and curative immunology, while in veterinary practice the various anærobic infections, especially, had victories to relate since 1930 .

So much for the set discussions : perhaps even more valuable, since they dealt with speculations too young and tender for the rough handling of public debate, were the private conversations during the afternoons free from open sessions. How many of these there were, one can judge only from observation of numerous groups of well-known workers with their heads together in eager talk. Such intercourse may well be the most fertile of all the Congress activities.

A full programme of 'scientific visits' had been arranged for the Congress members and most of the well-known institutes for microbiological research in and near London were 'at home' to visitors on at least one day during the week. The Ladies' Committee had, in addition, organized general excursions for sight-seeing round London which proved extremely popular. The Universities of both Oxford and Cambridge invited and entertained with generous hospitality large parties of Congress visitors.

The Congress closed on August 1 with a plenary session at which resolutions for the alteration of the name and statutes of the original International Society for Microbiology were adopted. Future triennial congresses are no longer only one of the activities of a society, in the sense of a body of society members, unlimited in number, but of a new 'Association of Microbiologists', limited in function mainly to congress organization and in number to one delegate from each participating country. Under the new constitution, the United States invited microbiologists to a congress in 1939 to be held in August on the Atlantic seaboard, and this invitation was accepted by the plenary session with acclamation.

\section{Fruit Supplies in 1935}

$\mathrm{U}^{\mathrm{s}}$ NDER the above title, the Imperial Economic Committee has issued a comprehensive supplement to its weekly fruit intelligence notes (London : H.M. Stationery Office, June 1936. 2s. 6d. net). It will surprise most citizens of the United Kingdom to know that only $79 \mathrm{lb}$. of fruit per head of the population was eaten in 1935 , as against an average of $96 \mathrm{lb}$. in 1934. Imports of raw fruit, however, exceeded those of any previous year, and made a total of $1,480,000$ tons. It is gratifying from an Imperial point of view that 53 per cent of this quantity came from Empire countries overseas, and the amount from this source was greater than the total imports from all sources in the years immediately preceding the Great War.

Home supplies show a rather disturbing variation from year to year, though the acreage under fruit crops does not fluctuate greatly. This is shown in the accompanying table, compiled from information on pages 12 and 14 of the volume, and relating to the orchards and small fruit in England and Wales :

\begin{tabular}{|c|c|c|}
\hline Year & Acreage & Yield, in cwt. \\
1929 & 313,295 & $11,098,000$ \\
1930 & 313,188 & $10,116,000$ \\
1931 & 306,801 & $5,371,000$ \\
1932 & 306,839 & $5,896,000$ \\
1933 & 309,553 & $9,445,000$ \\
1934 & 315,890 & $16,217,000$ \\
1935 & 321,963 & $4,387,000$ \\
\hline
\end{tabular}

If the yearly amount of home-produced fruit could be made more or less stable, the consumer would have the benefit of an increased, healthy diet of fruit, whilst the home producer and the importer would find a more uniform and workable market. The reason why the average consumption of fruit was $17 \mathrm{lb}$. more in 1934 than in 1935 seems to be that there was more than $3 \frac{1}{2}$ times the quantity from home sources in the former year than in the latter. Imports could not account for the increased consumption, for $27,069,000$ cwt. of fruit came into the country in 1934, and only a slightly larger amount, 29,593,000 cwt., in 1935. Damage by frost may possibly explain the extremely low yield of 1935 , though it was not wholly responsible for the small quantities produced in 1931 and 1932. It remains a potent factor, however, as a cause of fluctuating yield, and is beginning to receive the scientific study it deserves.* The so-called "biennial habit" of fruiting, where a year of high yield is followed by a lean season, is not obvious in the returns set forth above. Could not the growers and scientific workers of the country turn their attention to this rather obvious gap in the development of scientific distribution and controlled cropping?

"Fruit Supplies" gives very extensive analyses of the imports of fresh fruit, vegetables, flowers and bulbs into the United Kingdom, and reviews the output of various sources of supply. A useful feature is the statistics of imports into other countries, and the survey should be welcomed by all who are interested in watching the development of Empire resources.

*For example: B. O. Mulligan, "The May Frosts at Wisley", J. Roy. Hort. Soc., 60, 10 (Oct. 1935) ; A. N. Rawes, "An Orchardheating Experiment", ibid., 60, 11 (Nov. 1935); J. Grainger and A. L. Allen, "The Internal Temperature of Fruit tree Buds", Ann. App. Biol., 23, 1 (Feb. 1936) ; T. N. Hoblyn, "Spring Frosts at East Malling 1915-35", Ann. Rep. Elast Malling Research Station for 1935 (Msy 1936). 